\title{
ダイオキシンによる出生児の性未成熟の分子機構
}

\author{
武田知起

\section{Molecular Mechanism Whereby Maternal Exposure to Dioxin Suppresses Sexual Maturation of the Offspring after Growing Up}

\author{
Tomoki Takeda \\ Graduate School of Pharmaceutical Sciences, Kyushu University; \\ 3-1-1 Maidashi, Higashi-ku, Fukuoka 812-8582, Japan.
}

(Received June 21, 2017)

\begin{abstract}
Dioxins, including 2,3,7,8-tetrachlorodibenzo- $p$-dioxin (TCDD), are responsible for producing serious toxic effects in the next generation, such as sexual immaturity. Our laboratory found that treating pregnant rats on gestational day 15 with TCDD $(1 \mu \mathrm{g} / \mathrm{kg}$ orally) targets pituitary luteinizing hormone $(\mathrm{LH})$ to attenuate testicular steroidogenesis in fetuses. Because sex steroids during a short window ("the critical period") in the perinatal stage stimulate brain differentiation closely linked to sexual maturation, it is likely that TCDD imprints sexual immaturity on the offspring due to the lowered expression of LH during the fetal period. To address this hypothesis, we first investigated the effect of supplementation of equine chorionic gonadotropin (eCG), an LH-mimicking hormone, in fetuses exposed to TCDD. The result showed that eCG ameliorated defects in sexual behavior in adulthood as well as in steroidogenesis during the fetal stage. We also found that maternal exposure to TCDD induced the pituitary expression of histone deacetylases (HDACs) in fetuses. In agreement with this, TCDD deacetylated the histones wrapped around the LH $\beta$ gene, and valproic acid, an HDAC inhibitor, blocked the reduced level of LH $\beta$ caused by TCDD. These observations strongly suggest that TCDD induces the expression of HDACs to attenuate fetal LH production. Finally, such a transient reduction in steroidogenesis of the pituitary-gonadal axis causes a decrease in the expression of hypothalamic gonadotropin-releasing hormone, resulting in defects in sexual behavior in adulthood. This review increases our understanding of the developmental toxicities caused by endocrine disruptors including dioxins.
\end{abstract}

Key words__ critical period; dioxin; fetus; luteinizing hormone; sex steroid; sexual immaturity

\section{1.はじめに}

ダイオキシン類は，ごみの焼却過程や塩素を扱う 工場において非意図的に産生され，環境中に広く存 在する代表的な污染物質である. 実験動物を用いた これまでの研究から, 比較的高い用量のダイオキシ ン類を曝露した場合，曝露個体において消耗症，免 疫毒性及び発がんプロモーション作用など，多種多 様な毒性が生じることが報告されている.1)一方, 妊娠期母体への曝露によって児に出現する次世代影 響2)は，上記の毒性に比べて低用量で出現するため に問題が大きい。代表的な例として，妊娠期にダイ オキシン低用量曝露したラットを用いた研究によ

九州大学大学院薬学研究院（T812-8582 福岡市東区馬 出 3-1-1)

e-mail: takeda @ phar.kyushu-u.ac.jp

本総説は, 平成 28 年度日本薬学会九州支部学術奨励賞

の受賞を記念して記述したものである.
り，出産・成長後の児において，排卵低下や精子産 生能の低下並びに交尾行動障害等の性機能に異常が

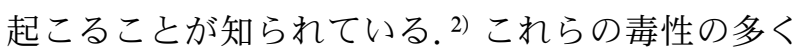
は，成獣への曝露によっては発現しないか，あるい はかなりの高用量を要することから, 発達期に感受 性が高く，時期特異的な影響が引き金となって成長 後にまで障害が固着するものと推定される。近年の 出生コホート調査からも, ダイオキシンがヒト次世 代の性特異的機能に与える影響が無視できないとの 報告が蓄積しており, ${ }^{3-5)}$ こどもの健康を守るため の対策の構築が望まれている.しかし，次世代影響 に関しては，発現機構はもとより毒性の実態さえも 不明な点が多く, 対処法を構築するにはまずこの点 を正確に理解しなければならない.

古くから，ダイオキシン類は内分泌摚乱作用，い わゆるホルモンの作用や代謝に影響を及ぼすことに よって障害性を示す可能性が示唆されてきた. ${ }^{1,2,6)}$ 
しかし, 発達期におけるホルモン擋乱作用の実態に 関しては十分に解析されておらず，次世代影響の根 本的な理解を目指した研究は明らかに不足してい た。このような状況を踏まえ，筆者が所属する研究 室では，最強毒性を有するダイオキシン同族体であ る 2,3,7,8-tetrachlorodibenzo- $p$-dioxin (TCDD)が, 胎児の性ステロイドに及ぼす影響に着目した解析研 究が行われてきた。その結果，妊娠（gestational day；GD） 15 日目の母ラットに対して $1 \mu \mathrm{g} / \mathrm{kg}$ TCDD を単回経口投与することにより，GD20の 胎児精巣において steroidogenic acute-regulatory protein (StAR) やCYP17 等の性ステロイド合成に 必須のタンパク質の発現が抑制される事実が発見さ れた. ${ }^{7,8)}$ さらに，これらの低下は精巣への直接作用 ではなく，上位制御因子である脸下垂体の黄体形成 ホルモン (luteinizing hormone; LH) の $\beta$-サブユ ニットの発現低下に起因することも見い出され た. ${ }^{7,8)}$

交尾行動能等の性特異的形質の獲得は, 脳の性分 化と密接に関係している。脳の性分化とは，臨界期 と呼ばれる特定期間（ラット：出生前後の10日間, ヒト：胎生 3-5 カ月と推定されている）に，性ステ ロイド刺激によって起こる脳の性別の決定機構であ る (Fig. 1).9,10) 脳は，性染色体に関係なくすべて 女性型として発生するため, 男児の場合には発達過 程で脳を男性型へと変換する必要がある。すなわ ち，臨界期において胎児精巣で合成された大量の性 ステロイドが，視床下部や視索を中心とする神経回 路に過不足なく作用することで脳の脱女性化と男性

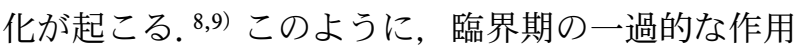
によって構築された神経回路の性差が，個体の一生 涯にわたつて性特異的な行動や特徵を決定づける.

上記の性ステロイドの役割と筆者の研究室における 先行研究とを合わせて考えると, ダイオキシンは臨 界期の性ステロイド合成抑制を標的として成長後に 交尾行動障害等の性未成熟を惹起するとの仮説が浮 上する．筆者は，この仮説の実証を通して，ダイオ キシンによる次世代影響の新規機構を提起すること を目指し研究に取り組んできた，本総説では，これ までの研究成果を概説するとともに，最近の成果と 展望についても紹介したい.

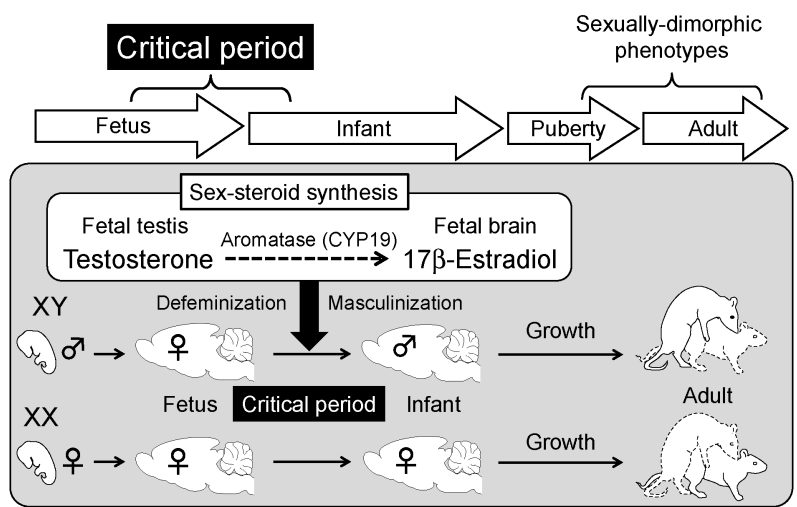

Fig. 1. Mechanism of Brain Sexual Differentiation

\section{2. ダイオキシンによる胎児期の脳下垂体 LH 低} 下の毒性学的意義

先に述べた通り，ラットにおける脳の性分化の臨 界期は，出生数日前から生後 5 日目あたりまでと考 えられている. 9) 筆者はまず，臨界期の期間全体に おける性ステロイド合成能力に対する TCDD の影 響を精査した。その結果，GD15 の妊娠ラットへの $\mathrm{TCDD}$ 曝露は GD20 の胎児から生後 2 日目まで $L H \beta$ mRNA 及び StAR/CYP17 mRNA の発現を低 下させるが，それ以降は影響が消失することが判明 した [Figs. 2(A) and (B)]. 11-13) さらに，これらの $\mathrm{ED}_{50}$ は 0.3-0.5 $\mu \mathrm{g} / \mathrm{kg}$ 程度 ${ }^{14)}$ であること, 並びに雌

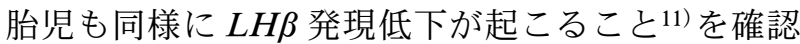
した，そこで続いて，一過的な $L H \beta$ 及び性ステロ イドの合成低下が，脳の性分化を障害することで成 長後に性未成熟を惹起する可能性を検討するため, 胎児への LH 補給実験を実施した。もし，胎児期 の LH 発現低下が成長後にみられる障害の原因で あるならば，不足する本ホルモンを補給することで 改善するはずである. LH 様ホルモンである equine chorionic gonadotropin (eCG) を用いて検討を行つ たところ， TCDD 曝露胎児への $\mathrm{eCG}$ 補給は，胎児 期に起こる StAR 及び $C Y P 17$ の発現低下のみなら ず, 7,8) 出生・成長後に出現する交尾行動障害をもほ ぼ正常レベルにまで改善させた [Figs. $2(\mathrm{C})$ and (D) ]. ${ }^{11)}$ これら一連の成果から，ダイオキシンは 出生前後の一過的な LH レベルの低下によって性 ステロイド合成を抑制し，成長後に交尾行動障害等 の性未成熟が出現するとの新規毒性機構が実証され た. 

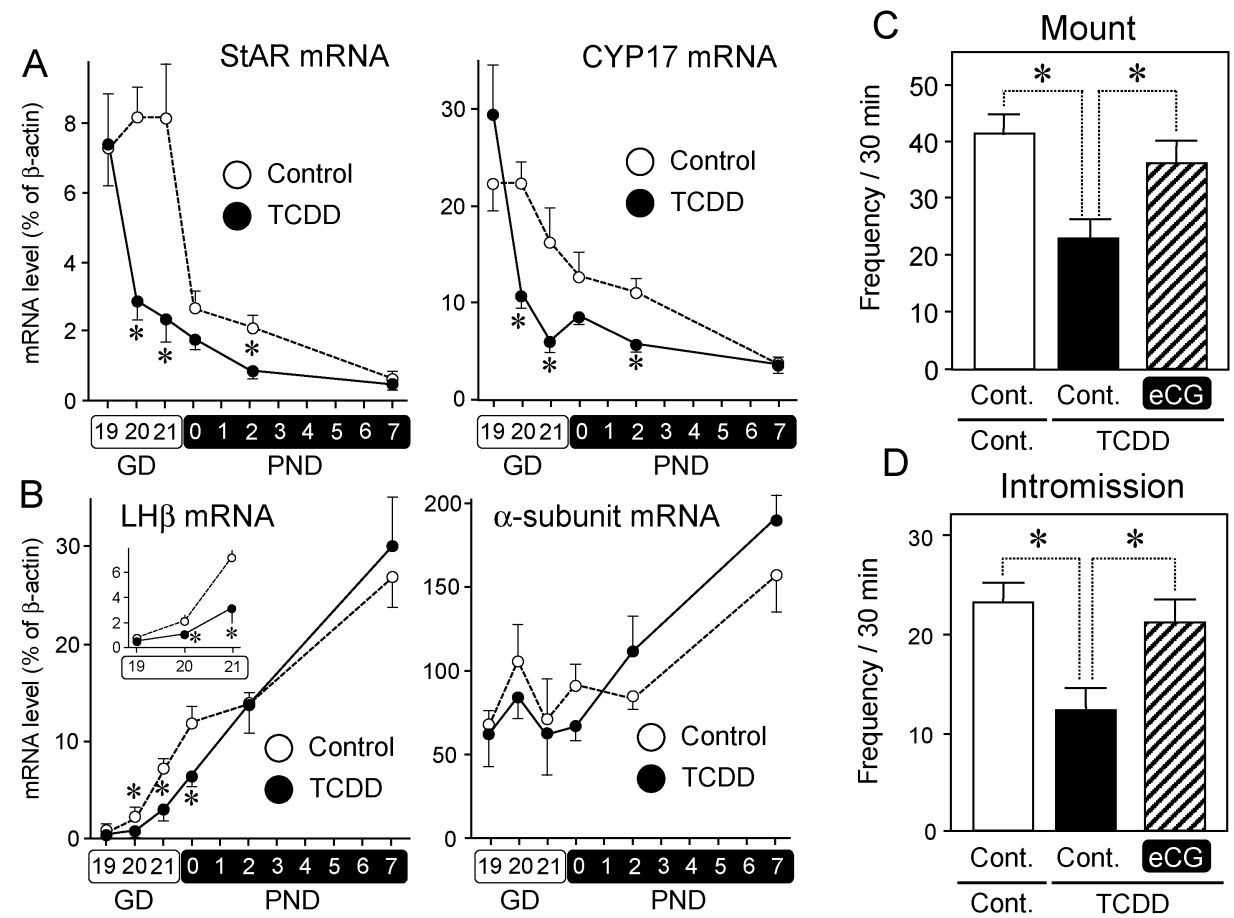

Fig. 2. Effect of Maternal Exposure to TCDD on the Expression of Steroidogenic Proteins and LH during the Perinatal Stage, and Recovery from the TCDD-produced Defects in Sexual Behaviors at Adulthood by in Utero Injection of eCG ${ }^{11-13)}$

(A and B) Pregnant rats at GD15 were given oral TCDD $(1 \mu \mathrm{g} / \mathrm{kg})$, and the fetal and neonatal tissues were collected during GD19 and postnatal day (PND) 7 . The expressions of mRNAs coding for testicular StAR and CYP17 (A), and pituitary LH (B) were determined by real time RT-PCR, and normalized by $\beta$-actin mRNA. The inset in B is a graph that magnifies the data of GD19-21. Each plot represents the mean \pm S.E.M. of 6-10 fetuses (neonates) that were removed (born) from different dams. (C and D) The masculine sexual behaviors of male offspring were measured at an age of 10 and 13 weeks. The bars are the means \pm S.D. $(n=3$ dams; at least two offspring born from one dam were analyzed). Significant difference: ${ }^{*} p<0.05$. Adapted from Takeda et al. ${ }^{11-13)}$ with slight modification.

\section{3. 胎児期の $L H \beta$ 発現低下の分子機構}

続いて, $L H \beta$ 発現低下の機構解析の手始めとし て，筆者は培養胎児脳下垂体を用いた ex vivo 実験 に着手した。すなわち，GD20の胎児より単離した 脳下垂体に対して TCDD を添加したところ，LH 合成の上位制御因子であるゴナドトロピン放出ホル モン (gonadotropin-releasing hormone; GnRH) に よる $L H \beta$ 発現上昇に対して有意な拮抗作用を示す

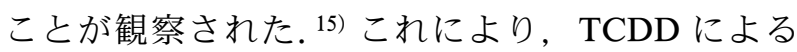
$L H \beta$ 発現低下には, 胎児脳下垂体に対する直接作 用が寄与することが推定されたため，引き続き DNA マイクロアレイ解析により標的因子を探索し た。その結果，複数のヒストン脱アセチル化酵素 (histone deacetylase; HDAC) の発現が，TCDD 依 存的に胎児脳下垂体において誘導されることを見い 出した. ${ }^{12)} 11$ 種の HDAC アイソフォームのうち, $L H \beta$ 転写制御への寄与が示唆されている16) $H D A C 1,5$ 及び 7 が $L H \beta$ 発現低下と同時期である 出生前後において誘導されることが確認された

[Fig. 3 (A) ] . 12) これらの $H D A C$ 発現変動は, 胎児
視床下部や母体においては生起せず，胎児脳下垂体 に選択的であった. ${ }^{12)}$ これらの結果を支持して, TCDD によって胎児脳下垂体の $L H \beta$ 遺伝子に会合 するヒストンタンパク質の脱アセチル化が充進した が，他の脳下垂体ホルモン遺伝子並びに母体 $L H \beta$ 遺伝子のヒストンアセチル化には影響を認めなかつ た [Fig. 3(B)]. ${ }^{12)}$ さらに, HDAC 阻害剤であるバ ルプロ酸を併用することにより，胎児の $L H \beta$ mRNA 並びに血中 LH レベルの低下が正常水準に まで改善された $[\mathrm{Fig} .3(\mathrm{C})]$. ${ }^{12)}$ 以上の結果から, $H D A C$ 発現誘導に基づく $L H \beta$ 遺伝子のヒストン脱 アセチル化の克進が，TCDD による $L H \beta$ 発現低下 に重要であることが強く示唆された.

一般に，ダイオキシンによる毒性発現には，芳香 族炭化水素受容体（aryl hydrocarbon receptor; AHR）活性化を通した遺伝子発現変動が重要であ ると考えられている. ${ }^{1,17)}$ AHR は， basic helix-loophelix/Per-Arnt-Sim-family に属する受容体型転写因 子であり, ${ }^{18)}$ その重要性は, $A H R$ 遺伝子欠損動物 においては多くのダイオキシン毒性が消失する事実 

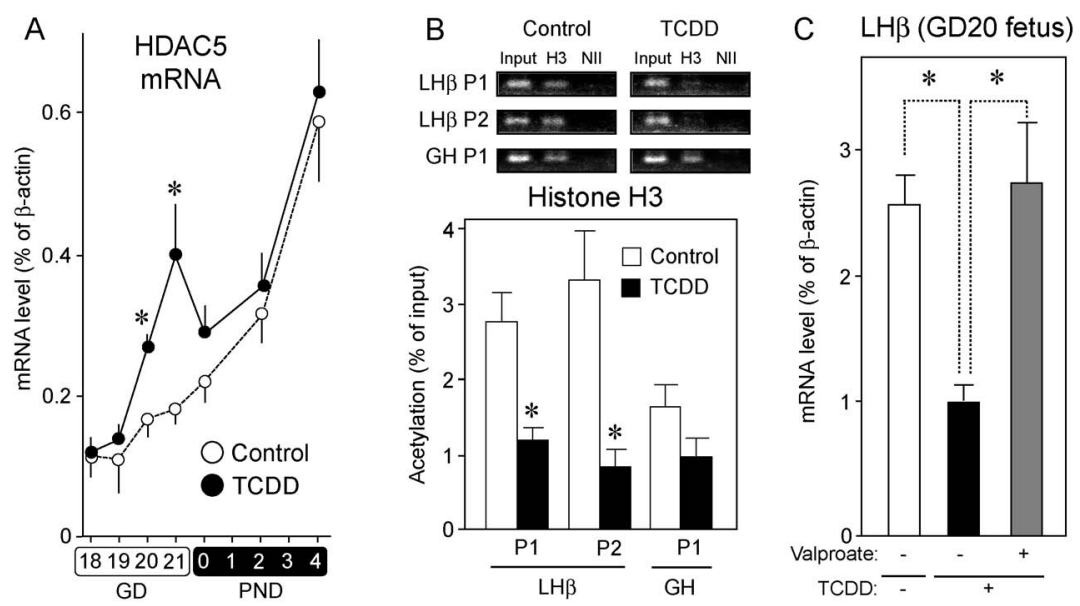

Fig. 3. The Role of the Induction of Histone Deacetylase (HDAC) mRNA in the TCDD-produced Attenuation of the Pituitary Expression of $\mathrm{LH} \beta$ during the Fetal and Neonatal Periods ${ }^{12}$

(A) The level of pituitary HDAC5 mRNA during GD18 and PND4 was determined by real-time RT-PCR, and normalized by $\beta$-actin mRNA. (B) The acetylation of histones $\mathrm{H} 3$ in the male fetal pituitary was analyzed by a chromatin immunoprecipitation method. In the upper panel, two regions (P1 and P2) of the LH $\beta$ promoter and a region of the growth hormone $(\mathrm{GH})$ promoter were separately amplified by PCR, and electrophoresed on $1.5 \%$ agarose gel. $\mathrm{H} 3$ and NII represent the samples immunoprecipitated with anti-acetylhistone $\mathrm{H} 3$ and non-immune IgGs, respectively. In the lower bar graph, the relative level of histone acetylation was analyzed by real-time PCR, and normalized by each input sample. (C) Pregnant dams exposed to TCDD $(1 \mu \mathrm{g} / \mathrm{kg}$, given orally) at GD15 were further treated with sodium valproate $(200 \mathrm{mg} / \mathrm{kg} / \mathrm{d}$, given orally) during GD16 and 19. Each plot/bar represents the mean \pm S.E.M. of 6-10 fetuses (neonates) that were removed (born) from different dams. Significant difference: ${ }^{*} p<0.05$. This research was originally published in the Journal of Biological Chemistry. Takeda T. et al., Dioxin silences gonadotropin expression in perinatal pups by inducing histone deacetylases: a new insight into the mechanism for the imprinting of sexual immaturity by dioxin. J. Biol. Chem., 2012; 287: 18440-18450. ${ }^{\circ}$ the American Society for Biochemistry and Molecular Biology.

から支持される. ${ }^{19-22)}$ 筆者は，LH 及び性ステロイ ドの合成低下に対しても，AHR が関与するか否か を明らかにするため, リガンド親和性の異なる AHR を発現する 2 系統のマウスを用いた検討を実 施した。本法は，AHR の寄与を簡便に解析できる 手法として古くから用いられている. ${ }^{23)}$ 高親和性 AHR を有する C57BL / 6J 系統の妊娠マウスへの TCDD 曝露により, GD18 胎児から生後 4 日目に かけて同様に LH の発現が低下し，ラットのみな らずマウスにおいても同様に臨界期の性ステロイド

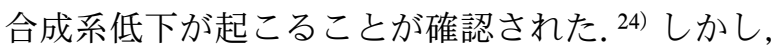
低親和性 AHR を発現する DBA/2J マウスでは, 同様の効果を引き起こすためには数十倍の高用量が 必要であった. ${ }^{24)}$ 以上のように, TCDD は AHR 活 性化を通して胎児脳下垂体の $H D A C$ 発現を誘導し,

$L H \beta$ 及び $S t A R / C Y P 17$ 等の性ステロイド合成系夕 ンパク質の発現を抑制することが強く示唆された。

\section{4. 成長後の交尾行動障害を規定する因子の同定}

脳の性分化の主たる標的部位の 1 つである視床下 部では，臨界期の性ステロイド刺激によって神経細 胞の集合体である神経核の密度や大きさに性差が生 じる。これによって生じる神経核は，性的二型核 （sexual dimorphic nucleus; SDN）と呼ばれ，成長後 の交尾行動を始めとする性特異的形質を制御する本
体であると考えられている. 9,25) 例えば，視床下部 にある視索前野（preoptic area; POA）には雄に優 位な神経核である SDN-POA が存在し，これを破 壊することで雄特異的交尾行動が抑制される. ${ }^{26)} こ$ のことから，TCDD による臨界期の性ステロイド 合成抑制は，性特異的形質に係わる視床下部神経へ の影響を通して成長後にまで障害を固着する可能性 が考えられる．筆者はまず，この可能性の検証に向 けた手がかりを得る目的で，成熟児（70日齢）の 視床下部を用いて DNA マイクロアレイ解析を実施 した。 その結果，胎児期の TCDD 曝露によって交 尾行動発現に重要な神経ペプチドホルモンである GnRH の mRNA レベルが低值を示す事実を発見し た. ${ }^{13)}$ 成長後にみられる $G n R H$ 発現低下は，生後 4 日目から持続的にみられた [Fig. 4(A)]。さらに, $\mathrm{TCDD}$ 曝露出生児に対して脳室内に $\mathrm{GnRH}$ を補給 することで, 交尾行動障害がほぼ正常水準にまで改 善したことから [Fig. 4(B)], 脳内における本ホル モンの低発現状況が，成長後の交尾行動障害の主因 であることが明らかになった. ${ }^{13)} G n R H$ 発現低下が みられる生後 4 日目は, 神経成熟期の最中であり, 性ステロイド依存的な臨界期の時期とも合致する.

筆者は，性ステロイド刺激の不足が GnRH 分泌に 係わる神経の成熟を障害することで GnRH 発現低 


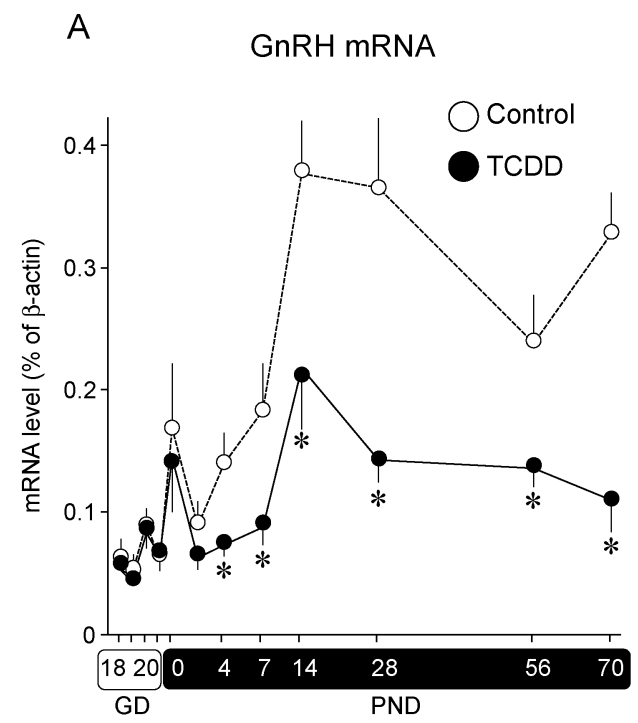

B Intromission (10-11 weeks old)

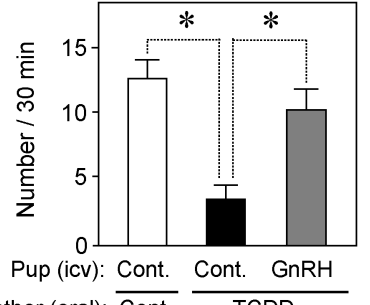

Mother (oral): $\overline{\text { Cont. }} \frac{\text { TCDD }}{\text { TCD }}$

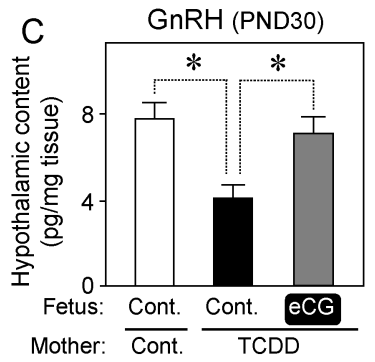

Fig. 4. Maternal Exposure to Dioxin Imprints Defects in Sexual Behaviors of the Offspring through Fixing the Status of the Reduced Expression of Hypothalamic GnRH ${ }^{13}$ )

(A) The levels of hypothalamic GnRH mRNA during GD18 and PND70 were determined by real-time RT-PCR, and normalized by $\beta$-actin mRNA. (B) Male pups at 9 weeks born of dams treated with TCDD at GD15 underwent intracerebroventricular (icv) infusion using a cannula-connected to an osmotic pump filled with $200 \mathrm{ng} \mathrm{GnRH} / \mathrm{mL}$ saline containing $0.1 \mathrm{~m} \mathrm{HCl}$. The number of intromissions was observed at 10 and 11 weeks. (C) The TCDD-exposed fetuses were injected with eCG at GD17, and the hypothalamic protein levels of GnRH were determined by an enzyme-linked immunosorbent assay. Each plot/bar represents the mean \pm S.E.M. of 6-10 fetuses (neonates) that were removed (born) from different dams. Significant difference: ${ }^{*} p<0.05$. Adapted from Takeda et al. ${ }^{13)}$ with slight modification.

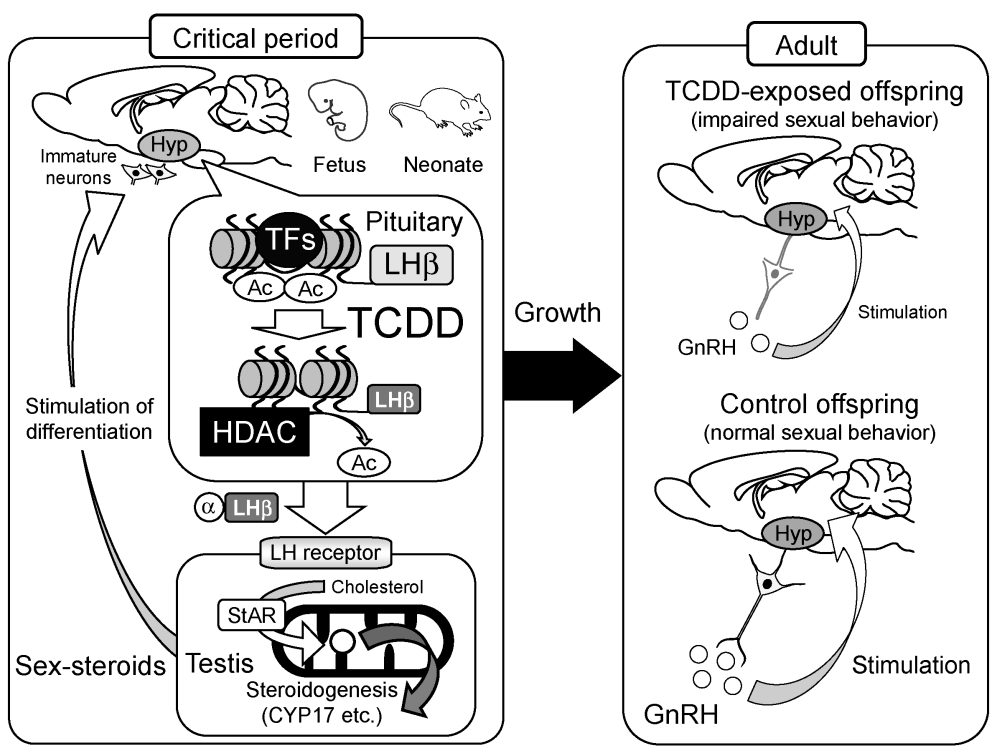

Fig. 5. Proposed Mechanism Whereby Maternal Exposure to TCDD Causes Sexual Immaturity of the Offspring after Reaching Maturity

下をもたらす可能性を想定し，胎児への LH 補給 による効果を検証した。その結果，TCDD 曝露胎 児への eCG 補給により，脳内の $\mathrm{GnRH}$ レベルは正 常水準に回復することが確認された $[\mathrm{Fig} .4(\mathrm{C})] .{ }^{13)}$ 以上の成果から，ダイオキシンは胎児期の一過的な LH の発現低下によって出生・成長後に至るまで
$G n R H$ 発現低下を固着させ，交尾行動障害が惹起 するとの一連の分子機構が実証された。現在, $\mathrm{GnRH}$ ニューロンの成熟や形態に着目した研究を 進めており，胎児期においては見かけ上の影響は認 めないが, ${ }^{27)} G n R H$ 発現低下が起こる乳児期には一 部に形態的な影響が観察されている（未発表デー 
夕)。引き続き，TCDD が GnRH ニューロンに及 ぼす影響とこれに対する性ステロイドの寄与に着目 した研究を展開していくことが重要と思われる.

5. おわりに

筆者は現在までの研究により，ダイオキシンが出 生前後に一過的な $H D A C$ 誘導によって $L H$ 発現を 抑制し，性ステロイド合成を低下させること，並び にこの一過的な影響が引き金となって GnRH の低 発現状態が成長後にまで継続し, 交尾行動障害が起 こる一連の毒性機構を明らかにした（Fig. 5)。本 成果は，発達期特異的な影響という新たな視点から のアプローチが本質を理解するために肝要であるこ とを明確に示した点で, 発達毒性学的研究における 新たな展開となるものと思われる。一方，発達期の ホルモン刺激による脳分化の分子標的や機構は，い まだ十分には理解されていない。筆者は，ごく最近 に作製した AHR 欠損ラットを用いて，ダイオキシ ンによる肝毒性の発現機構に関する解析も行ってい る. ${ }^{28)}$ この遺伝子改変動物等も用い, 本研究をさら に発展させることで，ダイオキシンの次世代影響と その機構を明確にするとともに，臨界期における刺 激が動物の成長や成熟にどのように寄与するのかを 理解するための重要な基礎情報を提供していきたい.

謝辞本稿を終えるにあたり，本研究の機会を 頂き，何時も絶え間ない懇切丁寧なご指導並びにご 鞭撻を賜りました九州大学大学院薬学研究院分子衛 生薬学分野の故山田英之教授（九州大学主幹教授, 平成 28 年 2 月 22 日，胃がんにより逝去，従四位 瑞宝小綬章）に対して，謹んで御礼申し上げるとと もに，心よりご冥福をお祈り申し上げます。

多くのご助言やご支援を賜りました石井祐次准教 授, 並びに現・崇城大学 石田卓巳准教授に深く御 礼申し上げます。ささに，本研究の実施にあたり， 胎児への直接投与法を始めとする技術指導，並びに 多くのご意見・ご助言を頂きました九州保健福祉大 学薬学部薬理学第 2 講座 武藤純平講師に謹んで感 謝申し上げます。また，脳室内投与技術をご教授頂 きました九州大学大学院薬学研究院臨床育薬学分野 の島添隆雄准教授に御礼申し上げます。さらに，本 研究は分子衛生薬学分野の卒業生並びに在校生の学 生の皆様のご支援やご協力があってこそ成し得たも のであり，この場を借りて謹んで感謝の意を表しま
す。最後に，このたびの学術奨励賞の選考委員の先 生方，並びにご推薦頂きました福岡大学薬学部 山 野茂教授に深謝致します。なお，本研究の一部 は, 日本学術振興会科学研究費補助金若手研究 (B) （課題番号：23790152）のご支援の下に行われまし た.

利益相反＼cjkstart開示すべき利益相反はない.

\section{REFERENCES}

1) Poland A., Knutson J. C., Annu. Rev. Pharmacol. Toxicol., 22, 517-554 (1982).

2) Peterson R. E., Theobald H. M., Kimmel G. L., Crit. Rev. Toxicol., 23, 283-335 (1993).

3) Grandjean P., Grønlund C., Kjær I. M., Jensen T. K., Sørensen N., Andersson A. M., Juul A., Skakkebæk N. E., Budtz-Jørgensen E., Weihe P., Reprod. Toxicol., 34, 498-503 (2012).

4) Winneke G., Ranft U., Wittsiepe J., KasperSonnenberg M., Fürst P., Krämer U., Seitner G., Wilhelm M., Environ. Health Perspect., 122, 292-298 (2014).

5) Nowack N., Wittsiepe J., Kasper-Sonnenberg M., Wilhelm M., Schölmerich A., PLoS One, 10, e0129906 (2015).

6) Vanden Heuvel J. P., Lucier G., Environ. Health Perspect., 100, 189-200 (1993) .

7) Mutoh J., Taketoh J., Okamura K., Kagawa T., Ishida T., Ishii Y., Yamada H., Endocrinology, 147, 927-936 (2006) .

8) Taketoh J., Mutoh J., Takeda T., Ogishima T., Takeda S., Ishii Y., Ishida T., Yamada H., Life Sci., 80, 1259-1267 (2007).

9) MacLusky N. J., Naftolin F., Science, 211, 1294-1302 (1981).

10) Arnold A. P., Gorski R. A., Ann. Rev. Neurosci., 7, 413-442 (1984).

11) Takeda T., Matsumoto Y., Koga T., Mutoh J., Nishimura Y., Shimazoe T., Ishii Y., Ishida T., Yamada H., J. Pharmacol. Exp. Ther., 329, 1091-1099 (2009).

12) Takeda T., Fujii M., Taura J., Ishii Y., Yamada H., J. Biol. Chem., 287, 18440-18450 (2012)

13) Takeda T., Fujii M., Hattori Y., Yamamoto M., Shimazoe T., Ishii Y., Himeno M., Yama- 
da H., Mol. Pharmacol., 85, 74-82 (2014).

14) Taura J., Takeda T., Fujii M., Hattori Y., Ishii Y., Kuroki H., Tsukimori K., Uchi H., Furue M., Yamada H., Toxicol. Appl. Pharmacol., 281, 48-57 (2014).

15) Takeda T., Yamamoto M., Himeno M., Takechi S., Yamaguchi T., Ishida T., Ishii Y., Yamada H., J. Toxicol. Sci., 36, 221-229 (2011).

16) Lim S., Luo M., Koh M., Yang M., bin Abdul Kadir M. N., Tan J. H., Ye Z., Wang W., Melamed P., Mol. Cell. Biol., 27, 4105-4120 (2007).

17) Whitlock J. P. Jr., Annu. Rev. Pharmacol. Toxicol., 30, 251-277 (1990).

18) Ema M., Sogawa K., Watanabe N., Chujoh Y., Matsushita N., Gotoh O., Funae Y., FujiiKuriyama Y., Biochem. Biophys. Res. Commun., 184, 246-253 (1992).

19) Fernandez-Salguero P. M., Hilbert D. M., Rudikoff S., Ward J. M., Gonzalez F. J., Toxicol. Appl. Pharmacol., 140, 173-179 (1996).

20) Schmidt J. V., Su G. H. T., Reddy J. K., Simon M. C., Bradfield C. A., Proc. Natl. Acad. Sci. USA, 93, 6731-6736 (1996).

21) Mimura J., Yamashita K., Nakamura K., Morita M., Takagi T. N., Nakao K., Ema M.,
Sogawa K., Yasuda M., Katsuki M., FujiiKuriyama Y., Genes Cells, 2, 645-654 (1997).

22) Harrill J. A., Hukkanen R. R., Lawson M., Martin G., Gilger B., Soldatow V., Lecluyse E. L., Budinsky R. A., Rowlands J. C., Thomas R. S., Toxicol. Appl. Pharmacol., 272, 503-518 (2013).

23) Poland A. P., Glover E., Robinson J. R., Nebert D. W., J. Biol. Chem., 249, 5599-5606 (1974).

24) Takeda T., Taura J., Hattori Y., Ishii Y., Yamada H., Toxicol. Appl. Pharmacol., 278, 220-229 (2014).

25) Lenz K. M., Nugent B. M., McCarthy M. M., Front Neurosci., 6, 26 (2012).

26) De Jonge F. H., Louwerse A. L., Ooms M. P., Evers P., Endert E., van de Poll N. E., Brain Res. Bull., 23, 483-492 (1989).

27) Takeda T., Matsuo Y., Nishida K., Fujiki A., Hattori Y., Koga T., Ishii Y., Yamada H., J. Toxicol. Sci., 42, 13-23 (2017).

28) Takeda T., Komiya Y., Koga T., Ishida T., Ishii Y., Kikuta Y., Nakaya M., Kurose H., Yokomizo T., Shimizu T., Uchi H., Furue M., Yamada H., J. Biol. Chem., 292, 10586-10599 (2017). 